\title{
RHOU Gene
}

National Cancer Institute

\section{Source}

National Cancer Institute. RHOU Gene. NCI Thesaurus. Code C114325.

This gene is involved in GTP binding, signal transduction and cell migration. 